\title{
EXAMINING THE RELATIONSHIP BETWEEN ESG SCORES AND FINANCIAL PERFORMANCE IN BANKS: EVIDENCE FROM G8 COUNTRIES
}

\author{
DOI: 10.17261/Pressacademia.2021.1524 \\ PAP- V.14-2021(50)-p.169-170
}

\section{Oguz Simsek ${ }^{1}$, Serkan Cankaya ${ }^{2}$}

${ }^{1}$ Istanbul Commerce University, Graduate School of Finance, Financial Economics, Istanbul, Turkey. osimsek@ticaret.edu.tr, ORCID: 0000-0001-7380-4454

2Istanbul Commerce University, Faculty of Business, Department of Banking and Finance, Istanbul, Turkey scankaya@ticaret.edu.tr, ORCID: 0000-0003-3010-0697

To cite this document

Simsek, O., Cankaya, S., (2021). Examining the relationship between ESG scores and financial performance in banks: evidence from G8 Countries. PressAcademia Procedia (PAP), 14, 169-170.

Permanent link to this document: $\underline{\text { http://doi.org/10.17261/Pressacademia.2021.1524 }}$

Copyright: Published by PressAcademia and limited licensed re-use rights only.

\begin{abstract}
Purpose- It is aimed to examine the relationship between the ESG scores and financial performances of all banks operating in the stock markets of G-8 countries (Italy, France, Japan, Canada, Russia, the United Kingdom and the United States).

Methodology- Return on assets and return on equity were used as financial performance criteria, and the Environmental, Social and Governance scores of the banks were defined as separate independent variables as sub-breakdowns. In addition, debt/equity ratio is another independent variable included in the study. The data used for the study were obtained from the Thompson Reuters database, the data were used on an annual basis and the data were analyzed with the panel data analysis method.

Findings- Results of the analysis, according to both return on assets (ROA) and return on equity (ROE) models, Environmental score has a negative and significant relationship, while Social score has a positive and significant relationship. Governance score has a negative and significant relationship on both sides. It was concluded that it was not statistically significant for both models.

Conclusion- In future studies, the performance of banks can also be examined on a country-specific basis and various different results can be obtained. In addition, examining real sector companies in future studies may help to obtain more striking results in terms of Environmental score, because the financial sector, and in particular the banking sector, has less environmental impact than other sectors. For example, it can be thought that the environmental scores of the airport's businesses or mining companies have more striking effects on profitability. Finally, the effects of year-specific ESG scores on bank performances can provide more explanatory results when considered lagged by establishing a dynamic model.
\end{abstract}

Keywords: Bank performance, ESG performance, sustainability, corporate finance, G8 countries JEL Codes: G39, M14, C33

\section{BANKALARDA ESG SKORLARI ILE FINANSAL PERFORMANS ARASINDAKI ILIŞKININ INCELENMESI: G8 ÜLKELERI ÖRNEĞI}

\section{ÖZET}

Amaç- Çalışmada G 8 ülkeleri (İtalya, Fransa, Japonya, Kanada, Rusya, Birleşik Krallık ve Amerika Birleşik Devletleri) borsalarında faaliyet gösteren tüm bankaların ESG skorları ve finansal performansları arasındaki ilişkinin incelenmesi amaçlanmıştır

Yöntem- Çalışmada finansal performans ölçütü olarak aktif karlılığı ve özkaynak karlılığı kullanılmış olup, bankalara ait Environmental (Çevresel), Social (Sosyal) ve Governance (Yönetim) skorları alt kırılımlar olarak ayrı ayrı bağımsız değişkenler olarak tanımlanmıştır Ayrıca borç/ özsermaye oranı da çalışmaya dahil edilen bir diğer bağımsız değişkendir. Çalışma için kullanılan veriler Thompson Reuters veri tabanından elde edilmiş olup, yıllık bazda veriler kullanılmış ve veriler panel veri analizi yöntemiyle analiz edilmiştir.

Bulgular- Analiz sonuçlarına göre hem aktif karlıı̆̆ı (ROA) hem de özkaynak karlılığı (ROE) modeline göre Environmental (Çevre) skoru negatif ve anlamlı bir ilişkiye sahipken Social (Sosyal) skorunun pozitif ve anlamlı bir ilişkiye sahip olduğu bulunmuştur. Governance(Yönetim) skorunun her iki model için de istatistiki olarak anlamlı olmadığı sonucuna ulaşılmıştır.

Sonuç- Gelecek çalışmalarda, bankaların performansları ayrıca ülkelere özgü olarak da incelenip, çeşitli farklı sonuçlar elde edilebilir. Ayrıca ileriki çalışmalarda reel sektör firmalarının incelenmesi Environmental (Çevre) skoru açısından daha çarpıcı sonuçlar elde etmeye yarayabilir, 
çünkü finansal sektör ve özelinde bankaclık sektörü diğer sektörlere nazaran daha az çevresel etkiye sahiptir. Örneğin havalimanın işletmelerinin veya maden şirketlerinin çevre skorlarının karlıık üzerinde daha çarpıcı etkilere sahip olduğu düşünülebilir. Son olarak ESG skorlarının belirli bir ülke grubundan ziyade, verilerin yoğunluk ve ulaşılabilirliğine göre ülke bazlı çalışmalar yapmak yorumlama yapabilme açııından daha çok katkı sağlayabilir. Son olarak, yıllara özgü ESG skorlarının banka performansları üzerindeki etkileri dinamik bir model kurularak gecikmeli olarak ele alındığında daha açıklayıcı sonuçlar sağlayabilir

Anahtar Kelimeler: Banka performansı, ESG performansı, sürdürülebilirlik, kurumsal finans, G8 ülkeleri JEL Kodları: G39, M14, C33

\section{REFERENCES}

Albertini, E. (2013). Does environmental management improve financial performance? A meta-analytical review. Organization \& Environment, 26(4), 431-457.

Alareeni, B. (2018). Does corporate governance influence earnings management in listed companies in Bahrain bourse?. Journal of Asia Business Studies.

Baird, P. L., Geylani, P. C., \& Roberts, J. A. (2012). Corporate social and financial performance re-examined: Industry effects in a linear mixed model analysis. Journal of business ethics, 109(3), 367-388.

Bénabou, R., \& Tirole, J. (2010). Individual and corporate social responsibility. Economica, 77(305), 1-19.

Brammer, S., \& Millington, A. (2008). Does it pay to be different? An analysis of the relationship between corporate social and financial performance. Strategic management journal, 29(12), 1325-1343.

Buallay, A. (2019). Sustainability reporting and firm's performance: Comparative study between manufacturing and banking sectors. International Journal of Productivity and Performance Management.

Cornett, M. M., Erhemjamts, O., \& Tehranian, H. (2016). Greed or good deeds: An examination of the relation between corporate social responsibility and the financial performance of US commercial banks around the financial crisis. Journal of Banking \& Finance, 70, 137-159.

Esteban-Sanchez, P., de la Cuesta-Gonzalez, M., \& Paredes-Gazquez, J. D. (2017). Corporate social performance and its relation with corporate financial performance: International evidence in the banking industry. Journal of cleaner production, 162, 1102-1110.

Friede, G., Busch, T., \& Bassen, A. (2015). ESG and financial performance: aggregated evidence from more than 2000 empirical studies. Journal of Sustainable Finance \& Investment, 5(4), 210-233.

Miralles-Quirós, M. M., Miralles-Quirós, J. L., \& Redondo-Hernández, J. (2019). The impact of environmental, social, and governance performance on stock prices: Evidence from the banking industry. Corporate Social Responsibility and Environmental Management, 26(6), 1446-1456.

Ofori, D. F., S-Darko, M. D., \& Nyuur, R. B. (2014). Corporate social responsibility and financial performance: Fact or fiction? A look at Ghanaian banks. Acta Commercii, 14(1), 1-11.

Shakil, M. H., Mahmood, N., Tasnia, M., \& Munim, Z. H. (2019). Do environmental, social and governance performance affect the financial performance of banks? A cross-country study of emerging market banks. Management of Environmental Quality: An International Journal.

Shen, C. H., Wu, M. W., Chen, T. H., \& Fang, H. (2016). To engage or not to engage in corporate social responsibility: Empirical evidence from global banking sector. Economic Modelling, 55, 207-225.

Soana, M. G. (2011). The relationship between corporate social performance and corporate financial performance in the banking sector. Journal of business ethics, 104(1), 133-148.

Wu, M. W., \& Shen, C. H. (2013). Corporate social responsibility in the banking industry: Motives and financial performance. Journal of Banking \& Finance, 37(9), 3529-3547. 